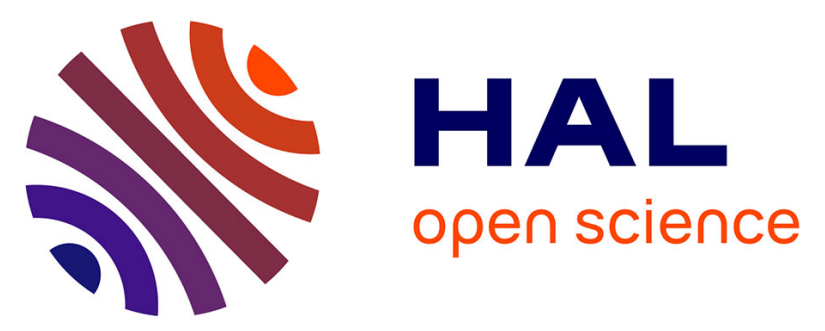

\title{
From Sport as an Instrument in Rehabilitation to the Adoption of Competitive Sport: Genesis of a Delegatee Sports Federation in France for Those with Physical Disabilities (1954-1972)
}

Sylvain Ferez, Sébastien Ruffié, Nicolas Bancel

\section{To cite this version:}

Sylvain Ferez, Sébastien Ruffié, Nicolas Bancel. From Sport as an Instrument in Rehabilitation to the Adoption of Competitive Sport: Genesis of a Delegatee Sports Federation in France for Those with Physical Disabilities (1954-1972). Sport History Review, 2016, 47 (2), pp.146 - 171. 10.1123/shr.20160002 . hal-01681374

\author{
HAL Id: hal-01681374 \\ https://hal.science/hal-01681374
}

Submitted on 26 Oct 2021

HAL is a multi-disciplinary open access archive for the deposit and dissemination of scientific research documents, whether they are published or not. The documents may come from teaching and research institutions in France or abroad, or from public or private research centers.
L'archive ouverte pluridisciplinaire HAL, est destinée au dépôt et à la diffusion de documents scientifiques de niveau recherche, publiés ou non, émanant des établissements d'enseignement et de recherche français ou étrangers, des laboratoires publics ou privés. 


\section{From Sport as an instrument in Rehabilitation to the adoption of Competitive Sport:}

Genesis of a Delegatee Sports Federation in France for those with Physical Disabilities (1954-1972)

\section{Sylvain Ferez, Sébastien Ruffié et Nicolas Bancel}

To date, very little research has examined the role of individuals in the emergence of disability sport in France. Some writers suggest that the Framework Act Favouring the Disabled (law $n^{\circ} 75-534$ of $30^{\text {th }}$ June 1975) was the main impetus heralding the advent of the sports federation for those with physical disabilities ${ }^{1}$. However, we argue that the birth of the movement cannot be pegged to this time frame, or even to the creation in 1963 of the Fédération Sportive des Handicapés Physiques de France (FSHPF) (Non-Profit Sports Association for the Disabled of France $)^{2}$. The historical accounts, which are often hagiographic ${ }^{3}$, produced by the people engaged in the Handisport Movement, place its origin in the pioneering drive of Philippe Berthe, founder in 1954 of the Amicale Sportive des Mutilés de France (ASMF) (Sports Club for the Mutilated of France - those having lost a limb or an organ) and first president of the FSHPF. The initiative had, at the time, no link with the movement that originated in 1948 at Stoke Mandeville (Great Britain), promoted by Ludwig Guttmann, a Jewish neurosurgeon who fled Germany early in 1939. Guttmann developed an innovative approach based on physical activity, a method which he presented publicly during an archery competition held on the opening day of the 1948 Olympics $^{4}$. In France, Berthe ignored the work of Guttmann and it was only following a training period he spent with Austrian skiers in the winter of 1953-1954 that he founded the $A S M F^{5}$. He developed this 
through a network of war veterans with the aim of extending the social movement of mutual assistance and claim for rights that was initiated after the First World War ${ }^{6}$.

In this context, we argue that, in France, the evolution from the rehabilitation through sports model towards the competitive sports model derived from the impact of the Rome Summer Olympics (1968). Furthermore, we propose that this was also linked to the special relationship developed from 1958 onwards between the new French High Commission for Youth and Sport and the High Commissioner Maurice Herzog. Finally, a third source for this development was the advent of the status of Delegatee Federation, which granted them institutional autonomy as well as the exclusive responsibility for organising competitions at any level $^{7}$. This constituted a distinctive step, which must be understood by taking into account the views of those involved ${ }^{8}$.

Many scholars have studied the change from the use of sport based on a medical approach for managing disability (personified by the Stoke Mandeville Games) to an approach incorporating high level competitive sport (represented by the Paralympic Games) ${ }^{9}$. In France, this evolution took place during a period when there was a huge increase in the number of participants taking part in such activities ${ }^{10}$, with the number of registered disabled Federation members doubling between 1958 and $1968^{11}$. Furthermore, this coincided with the establishment of the administrative structure for Youth and Sports. Under the Constitution of the Fourth Republic (October 1946 to May 1958), the paucity of the budgets granted to the Director General of Physical and Sports Education, Gaston Roux, cast the spotlight on the shortage of sports installations and the limited public policies intended to promote sports ${ }^{12}$, but a new impetus was apparent at the start of the Fifth Republic ${ }^{13}$.

The High Commission for Youth and Sport initiated in 1958 was transformed into a State Secretariat in 1963, before François Missoffe became a minister in full in 1966. In less than a decade, a proper administration was set up with unprecedented autonomy regarding National 
Education ${ }^{14}$. Through the laws encouraging the installation of sporting equipment and socioeducational programmes between $1961-1965$ ( $4^{\text {th }}$ plan $)$ and $1966-1970$ ( $5^{\text {th }}$ plan $)$, the policy initiated by De Gaulle brought the country to the cutting edge in terms of infrastructures, despite the time lost during the Fourth Republic, when both budget and sport facilities were lacking ${ }^{15}$. Simultaneously, sports education was officially introduced within National Education after 1967. Apart from networking the country with sporting equipment, the aim was to take advantage of the demographic weight that the youth in schools represented, in order to create a "mass sports culture", all the while trying to create an elite who could stand out in international competitions ${ }^{16}$. Did these political reforms influence the future of sports for those with physical disabilities? While the archives of the High Commission for Youth and Sport reveal no trace of a link with the $A S M F$ or the $F S H P F$, two boxes of archives from the Ministry for Sport $(M S)$ attest to the existence of such a relationship beginning, in 1968 . One labelled "Other Correspondence" (1968-1972) ${ }^{17}$ and the other "Medical Commission of the FFSHP from 1970" (and up to 1975) ${ }^{18}$ exposes the role of the MS.

To illustrate our assertion, we also analyzed articles appearing in the bulletins of the $A S M F$ and the organisations that successively played a role in structuring sport for those with physical disabilities in France between 1954 and $1972^{19}$. For the period 1954-1963, our analysis is based on 33 issues of the Revue des Mutilés de France (RMF, 1955-1959) (Journal of the Mutilated of France) and of the ASMF Magazine (ASMF Mag, 1959-1964). The 14 issues of the $R M F$ varied in volume, from 11 pages for the first issue to 21 for the last, and mainly concentrated on information addressed to members. Other than internal promotion, the Revue published articles on the benefits of sport, focusing on particular exercises and provided a section on international events. An editorial by the president opened each edition and supplied considerable information on the policy and situation of the Association. The 19 issues of $A S M F$ Mag were more substantial (20 to 30 pages). They included dates of sporting 
events and information on various Association Commissions. For the period 1964-1972 our analysis is based on an examination of the first 31 editions of Second Souffle (SS) (Second Wind), the review of the FSHPF (1963-1968) before it became the Fédération Française de Sport des Handicapés Physiques (FFSHP) (French Sports Federation for those with physical disabilities). The new Federation's review was an average of some fifty pages. More widely distributed, the same sections as previously can be found within it, with the addition of the results to national competitions which take up several pages. Beyond the collective and regulated words conveyed by these various official bodies, which openly admit to "propaganda", this corpus of articles provides access to objective information on the organisational progress of the movement (through the minutes of general and public assemblies), and also on the nature of quite conflicting debates (even though the official line tended to attenuate the reasons for conflict) which provided the framework for the life of the movement. Changes in titles and editors, as well as the large number of authors represented, encouraged the expression of alternative if not competing opinions.

The method for extracting and exploiting the data from these sources is based on a systematic examination of the periodicals in order to isolate the key points; the data is then cross checked with the archives, as well as with the interview reports, when available. The method is also based on a qualitative analysis of the periodicals, which allowed us to survey the evolution of the organisations' positions, along with those of the agents within them. From this perspective, the analysis takes into account the way in which the reasoning of those involved expresses not only the organisational procedures adopted, particularly for sporting events, but also the communications strategy concerning how they are staged. It also looks into the successive stances which were taken and the nature of the debates that accompanied organisational developments. Finally, the emergence of an individual "disabled champion" appeared as an indicator of the changes in the organisation. On key points, our analysis 
benefited from crosschecking and clarifications offered through the addition of spoken $\operatorname{archives}^{20}$. As well as four group discussions, 17 individual interviews lasting between 90 minutes and 4 hours were conducted with board members, administrators, and the technical executives of the organisations under study (ASMF, FSHPF, FFSHP and the Fédération Française Omnisport pour Handicapés Physiques ${ }^{21}$, a dissident federation that existed between 1972 and 1977), in order to reconstitute some aspects of the atmosphere of the time and also shed light on the lines of conflict and on pertinent political and social issues ${ }^{22}$.

The period examined includes changes in status of the organisations studied, which in turn reflect significant changes in direction. An initial period, from 1954 to 1963, is noteworthy for announcing the $A S M F$ plan for rehabilitation through sport. This project was influenced by participation at the Rome Paralympics in 1960. The movement created by this participation strengthened relations with the High Commission and led, in 1963, to setting up the FSHPF. The second period, from 1963 to 1972, is remarkable for the progressive structuring of sport. It led to obtaining the status of Delegatee Federation. How was this change in status implemented, having been instigated by the leaders of the movement, with the intervention of the newly formed administration for Youth and Sports?

\section{Sport as a means of rehabilitation (1954-1963)}

In the aftermath of improvements in social protection, greatly strengthened by the French State with the inauguration of the Social Security system in $1945^{23}$, the law of $23^{\text {rd }}$ November 1957 (Regulations on the right to employment for persons with disabilities) defined the status of the disabled worker ${ }^{24}$. The Association des Paralysés de France $(A P F)^{25}$ was set up in 1933 and recognised to be of public utility from $1945^{26}$. Also, the Association catholique des malades de Berck ${ }^{27}$, founded by Suzanne Fouché, who in 1929 also inspired the Ligue pour l'Adaptation du Diminué Physique au Travail $(L A D A P T)^{28}$, led the way in the fight for social 
and political recognition for people with disabilities. With the prime objective of promoting rehabilitation through sport, the $A S M F$ was based on the premise in which a medical outlook was linked to a motion to claim legal rights. More clearly, this related to the difficulties war veterans had in leaving the war behind them and dealing with cultural demobilisation ${ }^{29}$. In this context, Marianne Lassus stressed the way in which, up to the 1950s, representations of a useful body continued to be influenced by the need to rebuild France: "Rehabilitation gymnastics, orthopaedics, and mending the body are all discussed; drawings show the right posture to maintain in class. There is a considerable propensity towards improving the body, both literally and metaphorically: straighten up the body to straighten up France."30 In 1958, the creation of the High Commission for Youth and Sport seemed to provide an impetus for adopting a policy based on sport. How would the High Commission take part in the reorientation of the $A S M F$ in the aftermath of the first Paralympic Games of 1960 ?

\section{Promoting rehabilitation through sport}

In the 1950s, the $A S M F$ made sure that the activities suggested to and undertaken by members were not viewed by the general public. These activities were primarily intended to convince doctors and personnel working in the world of rehabilitation, as well as officials, of the value of sport as a means of rehabilitation, as suggested by the Revue des Mutilés de France. The front pages of the first editions announced this objective clearly: "Undertaking sport as a means of rehabilitation and motricity therapy for the Injured and Infirm" ${ }^{31}$. Up until 1963, this objective was often reiterated. In 1957, the cover picture showing an amputee high

jumper bore the sub-title: "Motricity therapy... perseverance with effort" ${ }^{32}$. The following year, a comment accompanied a series of photos: "Rehabilitation and motricity therapy... become a game, thanks to sports" 33 . 
Among the means considered for achieving these aims, the second clause of the ASMF Articles of Association referred to a plan to set up a rehabilitation centre. In 1956, while congratulating himself on the success achieved, the general secretary of the Amicale pointed out the need to "catch up" with countries whose governments had given more help to "the physically weakened to recover the place to which they have a right". He also regretted that in France, young people had to do it all themselves "by begging here and there", in order to obtain an organisation whose social pertinence was never in doubt ${ }^{34}$. The authorities were alerted to the situation. Over and above the promotion of sports activities, public authorities were asked to establish a disabled worker status. In November 1957, when the necessary law was about to be voted following a sports meeting in Constance, Germany was cited as a model: "The Germans understood ages ago that a good dose of sport is the perfect motricity therapy. It is true that German Public Authorities help a great deal; in Germany, sport performed by the injured and infirm is truly considered a means of rehabilitation and motricity therapy." 35

At the end of the 1950s, the subject of the lagging French rehabilitation methods was a leitmotiv ${ }^{36}$ and the approach presented as ideal was that of the Isny Sport Sanatorium in Germany. There, as in France, the decline in tuberculosis due to the progress of mass vaccination (from the end of the 1920s) led to converting the buildings originally intended to isolate tuberculosis patients into rehabilitation centres. In 1953, a company set up by a group of disabled people acquired the Isny Sanatorium ${ }^{37}$. It financed one third of the running costs, the other two-thirds were covered by the Land of the Bade-Wurtemberg and the Ministry of Work of the German Federal Republic ${ }^{38}$. The therapy establishment, which could take up to 80 people, organised twelve one-month treatment courses a year, "with the aim of rehabilitating the injured through sport and under medical surveillance" 39 . It was "the only home of its type in Western Europe" ${ }^{40}$. The $A S M F$ contemplated "obtaining one or two places 
from time to time at the Sport Sanatorium for accompanied injured people who were able to speak a little German" ${ }^{41}$. Early in 1959, the desire to set up a rehabilitation centre on the Isny model was confirmed. Dr. Brauninger, who succeeded Dr. Seil in the role of first head of medicine at Isny in 1955, provided an evaluation of the requirements for setting up a centre in France $^{42}$. He offered his help for drawing up the plans, and then for training a doctor and a sports instructor. Two other centres along the same lines had already been set up, one in Bavaria and another in Finland.

In 1959, the prospect of a centre designed specifically for motricity therapy for those with disabilities (military as well as civil), by practicing gymnastics and other sports was raised at an interview between the $A S M F$ and Maurice Herzog, the recently appointed High Commissioner for Youth and Sports ${ }^{43}$. The proposal disappeared abruptly from the bulletins at the start of the 1960s, when a vision based on the Federal model rapidly became the sole option. This reversal did not follow an external intervention; no mention was made in the administrative archives of the links so recently forged with the High Commission. The change of position of $A S M F$ corresponded to a redraft of possibilities generated by the extension of its network and the proximity of the first Paralympics in Rome.

Until the start of the 1960s, the advice of doctors was well represented in the bulletin of the Amicale. Their cited opinions, focussing on the rehabilitative effects of sport, were taken as guidelines. Over and above their words, it was the medical legitimacy given to the merit of sport that is striking. When not actually written by doctors, the authors of the published articles attempted to explain the benefits, health wise, of the sport in which they specialised. In this context, the demonstrations organised by the Amicale were intended to increase the number of professionals and politicians involved in public health to be convinced of the rehabilitative value of sport; they were not intended to provide a show for the amusement of a 
large audience. On the contrary, this perspective revived the obsessive fear of seeing a reemergence of fairground curiosities or freak shows.

Thus, in 1956, the second edition of the $R M F$, explaining the history of the ASMF, referred to the embarrassment, at the beginning, felt by the disabled when performing in public and having "a sort of reserve about displaying their injuries to the eyes of all when going into a public pool or an unreserved training room"44. The General Secretary of the $A S M F$ stressed that: "We are not seeking in any way to create a show in order to amaze the crowd. (...) Therefore, it follows directly that we have no profit-making objective." 45

Furthermore, in early 1957 , the $A S M F$ violently opposed Guy Girard's proposal to climb Mont Blanc as a sporting endeavour, Girard having presented himself in several press articles as "World Rehabilitation Advisor" and "National Advisor for our Rehabilitation Association" and giving the impression that the Amicale subscribed to his views ${ }^{46}$. The same year, the April editorial of the $R M F$ stressed its refusal to "be considered a spectacle to entertain the public" and its rejection of "individual exploits", such as swimming across the English Channel ${ }^{47}$. The quest for the phenomenal was forbidden: "No! We are not fools or reckless, nor are we freaks." It was certainly not a case of "training super-disabled", but of achieving "team work" to "show our sceptical comrades" that if other "disabled and mutilated people" managed to undertake particular activities, they could do so too: "This is why any personal initiative cannot have our support, not even moral support." 48 The purpose was to show the serious and realistic nature of the enterprise and to stand apart from individual exploits that were the result of the efforts of just a few. The point was to give everyone access to sport.

\section{Amicale Networks}

While the $A S M F$ quickly made contact with the $A P F$ and $L A D A P T$, its leaders first notified the War Veteran's social network of its activities. From the Rhin et Danube circle, 
Berthe launched the Amicale project with several comrades who regularly assembled in a room made available to them by Marshal de Lattre's widow. The head office of the ASMF (and later that of the FSHPF) was based at the same address, a mansion in rue Paul Valéry, in the $16^{\text {th }}$ arrondissement of Paris. Changes in the composition of its Honorary Committee provide a good indication of the various networks mobilised for its expansion, dominated as it was by military personnel. In fact, the links established before 1954 with servicemen, their wives and with service doctors predominated, providing the support necessary for obtaining both suitable premises and financial support.

Geneviève de Galard de Heaulme, a nurse who had worked with the injured at Dien Bien Phu, was decorated on $29^{\text {th }}$ April 1954 with the Legion of Honour (the highest decoration in France) for her courage in Indochina ${ }^{49}$, and led the first French delegation at Stoke Mandeville in $1955^{50}$. Furthermore, at the end of the war, the two successors of Berthe at the head of the FSHPF, and then of the FFSHP, Pierre Volait and Marcel Avronsart, each married one of the nurses who had tended them ${ }^{51}$. In the mid 1950s, the Honorary Committee of the $A S M F$ also included Surgeon-General Sicé, Colonel-in-Chief Labrousse, who was responsible for the Institution Nationale des Invalides (INI) (National Institute for the Disabled), Colonel Gloria, President of the Association de la $2^{\text {ème }}$ Division Blindée (DB) (Association of the $2^{\text {nd }}$ Armoured Division) commanded by General Leclerc, the Rhin et Danube War Veterans Association for the $1^{\text {st }}$ French Army of General de Lattre de Tassigny, and the President of the association of the Corps Expéditionnaire Français en Extrême Orient (CEFEO) (French Far East Expeditionary Force). In addition to the support received by the widows of Marshal Leclerc de Hautclocque and Marshal de Lattre de Tassigny, who sponsored the Amicale, and by the Ministry of the Army and the War Veterans Ministry, contact with generous donors from the world of industry was achieved through former officers and resistants. 
The archives we examined shed no light on the details of those forming the entourage of the leaders of the $A S F M^{52}$; they did not indicate the actions they took, or reveal the way in which they influenced decisions. However, they did identify the networks that were more or less directly solicited so that the essential resources for developing activities could be obtained. Here, the Marshals' wives were in the front line in the name of religious and moral duty, supporting the soldiers that had been disabled under their husbands' command. Berthe's widow remembered that her husband did not hesitate to solicit the wives to obtain contacts and meetings: “They were good women, you know: 'Knock, knock Madam Marshal.' For their protégés, the door was always open: 'But of course, my dear Berthe, I'll go and talk to President what's-his-name: don't worry I'll open the right door... ${ }^{53}$ For the rest, the War Veteran networks seemed to express a solidarity on principle, on a non political basis, which enabled divergent opinions on the future of the colonial empire to be ignored. The subject of sports for those with disabilities thus neutralised the disagreements between the positions of the colonialists and the "ultras" of the CEFEO ${ }^{54}$ and those more moderate and pacifist of Rhin et Danube.

The members of the $A S M F$, for the most part young resistants enrolled in the Army of Liberation $^{55}$, did not hold particularly strong political convictions. To see their plans advance they could nevertheless count on benevolent support from the military world and from War Veterans' associations, as well as on the former resistants' network. Pierre-Louis Dreyfus, a resistant, as well as ship-owner and banker by inheritance, was a member of the Honorary Committee. In addition to the help given by the Figaro, a daily paper that published the bulletin, Dreyfus was a primary link with what the editors of the $R M F$ sometimes called "the Firms". Roger Stoll, holder of the Legion of Honour and a committed trade unionist defending the claims of retailers before the Ministries, soon joined this committee. In 1961, he became economic advisor to the $A S M F$. A former resistant, Stoll presided over the Union of 
Small and Medium Businesses and, from 1948, represented the Confédération Générale des Petites et Moyennes Entreprises (CGPME) - General Confederation of Small and Medium Businesses at the Economic and Social Council. Founded some four years earlier around Léon Gingembre, the CGPME followed a liberal and conservative tradition in favour of freedom from price control, reduced public spending and taxation, but also against dirigisme (a form of capitalist economy with a strong directive from the State $)^{56}$. Close to the Pinay government in 1952, between 1953 and 1957 Gingembrism provided, in the eyes of public authorities, a reasonable alternative to Poujadism ${ }^{57}$ and the Union de défense des commerçants et artisans $(U D C A)$ (the Union for the Defence of retail traders and artisans) ${ }^{58}$, its main trade union competitor.

The support from which the $A S M F$ benefitted in the world of the unions and political administration did not however match an unequivocal ideological affiliation. This was obtained through the trans-partisan network of the War Veterans who were called to fulfil high responsibilities. Paul Haag, who was seriously injured during the 1914-18 war, became honorary president of the Amicale in 1957. He had become a member of the Organisation civile et militaire (OCM) (Civil and Military Organisation) in 1940, and then of the National Resistance Council; he was Prefect of the Seine (1950-1955), and headed the Association du corps préfectoral (1959-1961) (Association for Prefectural Personnel) ${ }^{59}$. Under the Vichy government he was removed from office as Prefect of the Var for being a Free Mason ${ }^{60}$; he was a committed Gaullist. The Christian-Democrat centrist, Robert Buron, also signed up to the Honorary Committee of the ASMF. Also involved in the National Resistance Council, he rallied to the cause of the Mouvement Républicain Populaire (MRP) (the People's Republican Movement) after the War, becoming successively head of several ministries between 1951 and 1962. In 1957, he joined the board of the weekly paper La Vie catholique (Catholic Life $)^{61}$. Although he was not one of the war-injured, he had experience of the Berck-plage 
sanatorium at the end of the 1920s, where he spent time in the company of the Catholic bourgeoisie who instigated the first civil initiatives for the disabled to have the right to work $^{62}$. That is where he met Suzanne Fouché6 ${ }^{63}$, of $L A D A P T$, another high-profile supporter of the Amicale. Was it through these networks, among those actively campaigning for rehabilitation, that the Action Sponsorship Committee recruited the manager of the regional Social Security Office in Paris in $1960 ?$

The experience of illness, injury, or disability was thus a characteristic largely shared throughout the support networks. This experience, often linked to an engagement in the Resistance and/or to the recognition of "fighting capital" 64 , called on solidarity beyond political affiliations, capable of ranging from the conservative liberalism of Roger Stoll to the social Catholicism of Robert Buron, and including the Gaullism of Paul Haag. Left leanings were however absent, support being sometimes even given in defiance of the communists. Only Pierre Cochard, who arrived in 1958, and became treasurer of the FSHPF in 1963, revealed his socialism ${ }^{65}$. By contrast, while Cochard was classified as an exception, a Christian education quite noticeably characterised all the leaders interviewed. Thus, for example, in the mid 1930s Pierre Volait (who became president of the FSHPF in 1966), was at the same religious school in Tronche as Charles de Gaulle's nephews. Volait's mother was therefore close to the social and religious commitment of de Gaulle's sister-in-law, looking after his brother Jacques who became hemiplegic following an encephalitis epidemic in 1926. It may be surmised that a religious education, common to many executives and supporters, provided the conditions that encouraged the founding and initial direction of the $A S M F$, being favourably disposed towards charity and helping others, as was the case here.

During these first few years of the Amicale, on the one hand military circles helped find suitable premises for undertaking sport and provided logistical support when transport was needed (lending a bus, trucks and military planes for travelling overseas), as well as 
accommodation (making available barracks or tents); and on the other hand, the doctors responsible for military rehabilitation centres gave access to suitable facilities (from 1955 to 1957, most of the meetings took place in either the Fontainebleau centre or the Institut National des Invalides, or the Raymond-Poincaré Public Assistance Hospital at Garches), providing medical monitoring of the activities available and advice on how to undertake them (in order to ensure the safety of meetings) ${ }^{66}$. For example, in May 1956, an article signed "doc" was a reminder that rehabilitation requires specific, methodical exercises directly related to the disability of the individual. It therefore implied discipline and more or less tedious daily exercises before being able to move on to more enjoyable activities such as dancing or swimming ${ }^{67}$.

Up to the end of the 1950s, when the Honorary Committee was divided into the Medical Committee and the Sponsoring and Action Committee (in 1958), the support from the War Veteran network and the military world predominated. It was through these that the ASMF had access to economic, political and sports environments. On the international level, links existed with other War Veteran organisations through the intermediary of the World Veterans Federation (WVF). These relationships, essential up to the start of the 1960s, were put into perspective as the support from national institutions diversified. The project of the Amicale finally obtained support in the sports world from two representatives who gave their encouragement at the end of the 1950s: Gaston Roux and Maurice Herzog. The difference in the profiles of these two individuals clearly characterised the breech occurring in the foundations of the Fifth Republic, as well as in the autonomous administration of Youth and Sports. Gaston Roux was a senior civil servant of the Fourth Republic. In 1928, after a period at the École de Joinville (Joinville Military School) ${ }^{68}$, he was detached to the physical education service (thus reporting to the War Ministry) as a result of injury in the Rif War (Morocco; 1921-1926). Until 1938, he served in various offices under Léo Lagrange, through 
whom he was awarded the Legion of Honour, working subsequently for Jean Zay. Being sympathetic towards the SFIO (the French Section of the Workers' International - founded in 1905 and replaced in 1969 by the current Socialist Party), Lagrange became General Manager of Youth and Sports from 1948 to 1958. Truly the "Vice-Minister for Sports under the IV"th Republic" $" 69$, he had above all to manage the penury of resources ${ }^{70}$.

As head of the High Commission for Youth and Sports, Herzog obtained a political assignment (and not one as a senior civil servant) and generous resources. Presented as "resistant fighter, businessman and alpinist", he benefitted from the label "Technician Minister" far removed from partisan issues ${ }^{71}$. He wanted to build a pyramid style administration to achieve the Coubertin-type project, enlarging the practical sports base "to attract and involve the elite able to raise on high the colours of Gaullian France in international competitions"72. Before him, the project of Gaston Roux was not favourable to professional sport and in the spirit of Léo Lagrange, demanded a form of "sport-leisure" (linked to a qualifying sports diploma) enshrined in a "socialist conception of sport" adopting the project launched by Herzog, the $A S M F$ turned to the sports world. It was not that recruitment to the Amicale had changed, nor that its members suddenly became more sports "conscious". It simply was that the ties established with the administration of Youth and Sports, at the time of its structuring, opened new prospects to leaders who, up until then, had favoured war veteran solidarity networks as well as the organisational relations with the world of medical rehabilitation.

\section{The Paralympics Dynamic (Rome, 1960)}

The sporting dispositions taken by the founders left no doubts. At age 16, Philippe Berthe had joined the Resistance to satisfy his taste for adventure and his fiery temperament. At that time he hoped to become a physical education instructor. Forced to abandon this ambition 
following femoral amputation of his right leg, at the end of the 1940s he occasionally went to the Automobile Club ${ }^{74}$. In the 1950s, Huguette Tanguy (who had gone through poliomyelitis) met him through her brother, badly disabled by a war injury and who subsequently befriended Lionel Terray, a renowned alpinist who took part in the French Annapurna expedition led by Herzog in 1950: “Terray said to him: 'Don't worry, I'll see to your rehabilitation!' As my brother was a great sportsman, Terray took him for over a year and had him start skiing again. He got him into the French Alpine Club ... (...) and one day my brother saw a chap arrive who limped a bit, and he asked him: 'What are you looking for?' And he replied: 'Well now, I wanted to see if the disabled could enter .....' And my brother said to him: 'Well I'm disabled too! And the chap replied: 'What do you do?' They chatted and it was Philippe Berthe!"75

Similar situations occurred with Pierre Volait - even though they were more closely linked to family socialising than to life in the mountains ${ }^{76}$. He arrived at the $A S M F$ at the end of the 1950s (and succeeded Berthe at the head of the FSHPF in 1966). While a taste for sport was a driving force in mobilising the pioneers, it was not until the start of the 1960s that, thanks to a sporting event, an organisational change occurred which led to disregarding the rehabilitation objectives that had been announced at the start.

In 1960, the relocation of the Stoke Mandeville games to Rome marked a turning point. The event had profound repercussions on the organisation of the French movement. The organisation of competitions in the stadium where the "normal" Olympics had just taken place was presented as a successful conclusion ${ }^{77}$. The $A S M F$ suddenly saw in the Games a strategic means to advance the cause of those with disabilities. Although the medical seal of approval seemed vital, the links recently forged with the High Commission for Youth and Sport thanks to military circles - offered prospects for development that more closely matched the sporting taste of the pioneers. Reorientation towards sporting ends was quickly accepted, 
despite internal debates concerning competitions and the notion of champions which took place in 1959-1960.

On $27^{\text {th }}$ July 1960, just before the start of the Olympic Games, Herzog invited the specialist press to the High Commission and raised the prospect of the team winning fifteen to twenty medals for France. At the end of the Games, the sports lobby expressed its ire in the press at the absence of a gold medal, the disappointment of the Rome Games becoming an example of "Imperial France collapsing in on the Hexagon" and being a "parable of the National decline"78 - even more poignant as it occurred against the backdrop of the Algerian crisis. In this context, the results obtained in Rome appear as a nation-wide catastrophe. This disaster served as a justification for the first reforms initiated by De Gaulle regarding sporting policies, aimed at restoring the prestige of the Nation, which was the General's true obsession $^{79}$. Thereon, the aim was to continue these reforms. Herzog used the defeat as a means to get the government and the Parliament to accept the need to make a major investment in sports facilities ${ }^{80}$.

The controversy over the Rome Games thus offered a decisive opportunity to take steps towards implementing the transformation, in political and administrative terms, that had been in progress since 1958. This controversy revealed the sports and Olympics acculturation to which the French were subject during the 1960s, including the domain of disabled sports: "What is more, this 'sportivisation' of the French goes via a re-moralisation of sport, through the dissemination of a sports ethos and through imposing a pyramidal competitive approach which will pervade French mentality for at least half a century" ${ }^{\prime 1}$.

In September 1960, the $A S M F$ returned from the Paralympics Games with five gold medals. Hardly back from Italy, Berthe brought to fruition the "achievements of the whole French paraplegic delegation" $"$ 2 . He wrote to the High Commissioner, Maurice Herzog, who replied on $3^{\text {rd }}$ October, delighted by the "brilliant record of achievement of the French 
team" 83 . On $11^{\text {th }}$ October, the president of the French Olympics Committee addressed "its warmest congratulations" to the $A S M F^{84}$. On $2^{\text {nd }}$ November, it was the turn of the Minister for War Veterans, who suggested establishing contact with the press attaché in his office. While the media visibility of the Amicale remained mediocre, the Rome Games were "a propaganda success", that had enabled "many of the incredulous" to recognise "the value of sport as a means of physical and morale rehabilitation" 85 . The Games were furthermore the occasion for the $A S M F$ to strengthen its involvement within international sports meetings for the disabled.

The Rome Games also gave rise to the International Working Group for Sports for the Disabled (IWGSD) and significant appointments were made: Berthe as vice-president, Dr Maury as medical advisor and Michel Boubée as technical advisor. The IWGSD laid the foundations of the International Sports Organisation for the Disabled (ISOD), which was set up in 1964. The involvement of the $A S M F$ within the international sports movement enabled it to defend its ideas, in particular those concerning extending the Games to all types of disability. This position kindled tensions regarding the direction that sport for the disabled should take. Guttmann continued to defend the idea of sport solely for those with a motor disability $^{86}$

In July 1963, 370 participants assembled in Stoke Mandeville. The 29 French athletes present carried off twenty gold medals, 15 silver and 13 bronze. Yet, already, eyes were turning towards Tokyo. An initial meeting to "prepare preselections" was held at Fontainebleau on $4^{\text {th }}$ and $5^{\text {th }}$ July, followed in December by a "preparatory meeting for the Tokyo World Games" ${ }^{\prime 87}$. The movement was now organised along sports lines. Finally, two events were held in Japan: from $8^{\text {th }}$ to $12^{\text {th }}$ November 1964,375 paralysed athletes from 21 countries took part in the Paralympics; and from $13^{\text {th }}$ November, the National Sports Meet with 480 participants from 46 Japanese provinces, European athletes and a West-German team - was multi-handicap ${ }^{88}$, reflecting the French aspirations for opening to all deficiencies. 
Henceforth, the major sports event was no longer the annual event at the Stoke Mandeville Hospital, although a meeting was still held there, but there was now a Paralympics held every four years.

\section{Organisation on the Federal Model (1963-1972)}

Literature on the origins of the Paralympics movement clearly identifies the change from a medical rehabilitation approach to a sports approach ${ }^{89}$. This research is however unclear regarding the timing of this change, the personalities concerned and the nature of the process driving it from one approach to the other, and even more on the relationship between national developments and the international movement. While the Rome Games marked a decisive step, Peers favoured the institutional aspect over that of the managed event, considering the birth of the ISOD in 1964, as a turning point ${ }^{90}$.

France played a key role in setting up the ISOD $^{91}$. Following the first Paralympics of 1960, at a time when the International Stoke Mandeville Wheelchair Sports Federation (ISMWSF) stemmed from the International Stoke Mandeville Games Committee, the ASMF co-founded the International Working Group on Sports for the Disabled ${ }^{92}$. Philippe Berthe became one of its three vice-presidents, beside Ludwig Guttman and Dick Van Rijn (Netherlands) $^{93}$, while Curtis Campaign and then Norman Acton (both from the FMAC) took up the role of president ${ }^{94}$, and Gerd Brinkmann (Germany) the role of general secretary. Another Frenchman, Michel Boubée (physiotherapist at the Fontainebleau centre), whose orientation in favour of rehabilitation was dominant, was also part of the Sporting Committee of this Working Group. He had to endure the German Hans Lorenzen (president of the committee) and a representative of the Swiss Federation of Sports for Invalids, Marcel Meir, both of whom were known for their opposition to sporting competition for physically disabled 
people ${ }^{95}$. However, these links testify to the strengthening of the French handisport movement's grip on the international front and thus, of its legitimacy.

It was in line with these achievements that the ISOD was created, during a meeting of the International Working Group on Sports for the Disabled, which took place in Paris on the $18^{\text {th }}$ and $19^{\text {th }}$ of June 1964, in the presence of representatives from eleven European countries (Germany, Austria, Belgium, Finland, France, Italy, Luxembourg, Norway, The Netherlands, the United Kingdom, Switzerland ${ }^{96}$. The role played by France in setting up the ISOD would not have been visible without recognising the impact of the first Paralympics, as well as the links established with the High Commission for Sport at the end of 1959. These links were likely rather limited at the beginning of the 1960 s since they were neither recorded nor archived by the Youth and Sports administration.

The idea of becoming a sports federation arose on the return from Italy. This status was deemed a necessity for regulating the organisational difficulties caused by the significant development of the ASMF. Huguette Tanguy remembered the incentive of the High Commission: "And then, at that time, the Minister said to us: 'You mustn't stop there!' Because in a way we were draining all the bits and bobs... we were managing France from a room measuring four meters by five! It was impossible, it just couldn't continue!" She recalled the relations with Herzog: "It was him at that moment, so we said to him, laughing, 'look now, you're like us now, you are amputated too!', 97.

Just after founding the federation, Berthe commented that the Amicale had actually

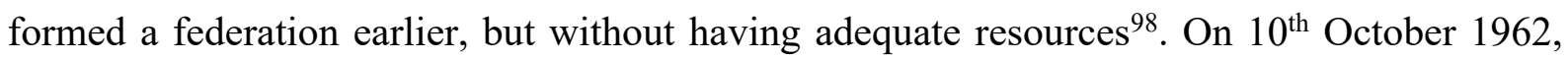
section delegates (from the Loire, Berck, Mulhouse, Nancy, Le Havre, Paris, Fontainebleau and Garches) and associated rehabilitation centres met to lay the foundations for a federal organisation. Provisional administrative officers were elected, with Berthe at their head. Tanguy was in charge of drafting the articles of association, together with one of Herzog's 
colleagues ${ }^{99}$. On $11^{\text {th }}$ May 1963, following a constitutional assembly for the federation, Berthe was elected President, and Tanguy General Secretary. One month later, Herzog was appointed Secretary of State for Youth and Sports.

The FSHPF was officially recognised on $10^{\text {th }}$ August 1963 , only ten months after the decree of $27^{\text {th }}$ November 1962 , by which the State strengthened its powers over sporting federations by imposing "standard articles of association", a regime of "ministerial approval", and a "delegation to public service" 100 . Straight after its official recognition, the FSHPF invited local sports sections and those working with hospitals to join the Federation in order to ensure coordination ${ }^{101}$. At the national level, it was a matter of "expanding the $A S M F$ movement by decentralising to a maximum through setting up local sports clubs" 102 and also to provide France with suitable sports amenities, to train instructor-monitors in each sport and to increase inter-regional meetings. At the international level, it was a matter of maintaining the sports rank obtained and devising ways for adapting sports to include all disabilities. To that end, it appeared vital to respond to foreign invitations and prepare for major events, in particular the Tokyo Games (1964). The connection between the FSHPF and the ASMF was clear, as was the orientation towards the sports world. It was based on reorienting the expectations generated by the Rome Games and the first contacts established with the High Commission for Youth and Sports.

\section{Emergence of a possibility: the arrival of a disabled champion}

In the second half of the 1960s, the sporting stakes took on a new shape within the activities of the Federation. After the Tokyo Games, the French championships saw a growing number of participants. At the turn of the 1960s-70s, the sports calendar was organised around the separation of regional, national and international levels, with the pyramidal view of identifying an elite. 
The international calendar included several important dates. In 1966, the European Games took place in Saint-Etienne. In June 1968, France attended the $6^{\text {th }}$ International Games in Brussels, organised every two years from 1958, but subsequently superseded by other specifically international events. Every summer, the Stoke Mandeville Games had a special status. André Hennaert, who attended from 1965-1966, remembered that the table tennis and fencing competitions were held outdoors, under canvas tents: "But there was a very high standard. And the athletes were not particularly difficult... from the moment they could take part in their sport they did not worry about the reception or the food; we took with us what we needed!'"103 In 1967, 30 French athletes took part; there were 45 in 1969. In the meantime, in 1968, the Paralympics took place in Tel-Aviv: while the French team comprised 20 athletes in Tokyo (1964), they were 55 in Israel ${ }^{104}$.

On their return, the good results achieved by the French once again attracted the attention of the Ministry of Youth and Sports (MS) of François Missoffe. The moment had now come for comparison with the able-bodied. The national trainer noted that the weight lifting event took place "in an atmosphere worthy of a major international competition for the ablebodied"105. The national swimming trainer registered significant progress: "Many countries take great pains to ensure that their swimmers arrive for daily training, like Britton, the English competitor $[\ldots]$ who told us that he trains five times a week [...]. I hope that this will encourage ours to go to the pool more than once a week, as many of our representatives do." 106 The table tennis trainer was already planning "the Paralympics preparation year". On the return from Stoke, the captain of the French team realized that they should force themselves to undertake "the severe training required for a Paralympics year"107. It must be said that in July 1967 the notion of "records" was officially introduced in the international rules: the Stoke Mandeville International Committee said that only world records beaten 
during national contests organised under its rules would be recognised. Thus, "champions" and "stars" would no longer give rise to apprehension.

The resources to produce performances were gradually set up. There was a constant reminder of the aim for rigorous and daily training. One of the imperatives of the national meetings became clearly to select the "best candidates" to compete in the Paralympics ${ }^{108}$. In this way, the French athletes were outstanding in the 1968 Tel Aviv Games. Indeed, several French records and one World record were broken in athletics. In archery, 36 of the 40 world records were "wiped from the slate" - including ten by the French: "the best scores achieved by the disabled are the same as the best able-bodied records of a few years ago"109. In basketball, France came away with the bronze medal.

However, while some deplored the casual dress and lack of preparation of a number of people, President Volait acknowledged the "very definite sports improvement" since Tokyo and the "brilliant French achievements" at Tel-Aviv (13 gold medals, 10 silver, 9 bronze, putting France in $5^{\text {th }}$ position among the 29 countries represented) ${ }^{110}$. In parallel, the perception of performance had matured, using the records as a reference scale for training guidelines. The "champion" thus appeared as a role model - like the fencer Schuh, who was portrayed as a hero. A logical selection procedure was essential. In weightlifting for example, the idea of setting up two series for the French Championships emerged, with a national value and an international value, by setting the "minima" for advancing from one to the other" This competitiveness generated tension. In May 1969, following the French table tennis championship, the Federal trainer noted: "It would be good if a little more authority silenced the unwelcome contestations from the real diva [sic] who, using the excuse of an unfavourable draw, proclaimed his dissatisfaction to the point of changing the organisation of the championships." 112 
For his part, the vice-president of the Federation regretted the lack of pennants and medals, and the absence of uniform clothing for the teams ${ }^{113}$. A few months later, following the $1^{\text {st }}$ International Games at Kerpape (near Lorient), the national athletics trainer took exception: "When a program has been decided by a Commission and fully specified by current regulations, no modification must be made $[\ldots]^{\prime 114}$. The supervisors of the various disciplines were insisting more than ever on "training" and "assiduity". This applied equally to the women and the youths who might "rest on their laurels". A way of saying that asceticism and sporting discipline had imposed themselves within categories which might have been exempt of them ${ }^{115}$. At a time when the figure of a disabled champion could be asserted, the lack of the seriousness and rigor required by competitive sport was condemned.

\section{A clearer relationship with the Youth and Sports administration}

It was in the last years of the sixties that the links with the $M S$ were reinforced, during a period when the increased membership generated management problems. It should be noted that the number of members consistently grew throughout the period being examined. The Amicale had some 50 members in 1955; it had 100 in January 1957 and 700 in May 1959. When the Federation was put in place in 1962-1963, the number of registered members was over 1000. Their number had reached 1500 by the start of the 1970 s.

In 1966, Pierre Volait took over from Berthe as the head of the Federation. This change in president was not anodyne. Berthe did not stand for re-election, stating business demands as his reason. While open conflict was avoided, tension was raised because of the financial difficulties being experienced by the Federation, which would seem to explain, more than a lack of availability, Berthe's reasons for withdrawing ${ }^{116}$. Volait proposed a program based on three main points, while stating that he would run for presidency for one year only ${ }^{117}$. His objectives were to ensure the development of the "movement while respecting the basic spirit, 
meaning sport for the greatest number of physically disabled". Although he claimed to admire, respect and encourage competitive sport, he wanted it to be undertaken by "the ordinary disabled person who is not financially self-sufficient. In a word, sport should be open to the greatest possible number of our friends, no matter what their abilities and the results they achieve in competitions". The number of members should therefore increase through the maxim of "sport for all". But it was also necessary to "balance the budget" by "relentlessly defending the 1967 Federation budget", and to increase meetings "locally, regionally and then internationally" 118 . Of the thirty-two members eligible to vote, thirty gave him their unconditional support and two abstained.

Alain Siclis, who arrived at the FSHPF in 1966, insisted on his status of owner-manager, while Berthe, "more belligerent" was more the embodiment of "the military culture and man in the field" ${ }^{119}$. Early in 1968, "the effort to balance the budget" remained a priority ${ }^{120}$. Volait, who had committed to a year, was still at the head of the Federation. In March, the President's report voted at the General Meeting hailed the "austerity measure" and the "spectacular recovery" which it enabled ${ }^{121}$. The deficit announced at end 1966 was absorbed; the financial year 1967 started with a surplus. For 1968, the expected income of 112,250 Francs came mainly from the Ministry for Sport (71,200 Francs). A hierarchy of financial priorities emerged, which led to releasing greater expenditure for purely sports purposes. Of the whole budget, 32,350 Francs were made available for national sports activities and 30,000 Francs for international events; the remaining 47,000 Francs being allocated to running the Federation ${ }^{122}$. Once the accounts were healthy, the emphasis of the Federation turned more obviously to competitive activities. In summer 1968, Volait warned those who were going to the Paralympic Games at Tel-Aviv that it was not a "tourist trip" at the expense of the Ministry sponsoring them ${ }^{123}$. 
In parallel, the contacts with François Misoffe's Ministry for Sport (inaugurated in January 1966) grew stronger by the end of 1967. Commandant Gaudefroy was appointed "Vice-Minister for Youth and Sports" for the Fédération Sportive des Handicapés Physiques de France $(F S H P F)$. This was the first time that the Federation appeared in the archives of the administration of Youth and Sports ${ }^{124}$. Gaudefroy henceforth served as the link between the office of the FSHPF and Colonel Marceau Crespin, Director of Physical and Sports Education, to whom he regularly addressed notes on this subject. In the 1990s, under Herzog's authority, in the same way as under Misoffe's, Crespin was the main promoter of an organisation model of sports, based on municipalities and clubs, in order to develop a true "public service" for sports on a local level ${ }^{125}$. On $1^{\text {st }}$ July 1968, Huguette Tanguy, General Secretary of the Federation, sent Gaudefroy copies of the four requests sent to $M S$ between $18^{\text {th }}$ January 1967 and $12^{\text {th }}$ March 1968 and which had "remained unanswered". She recalled: "When they saw me arrive at the Ministry, I remember them saying: 'Oh my! Better give her something because she'll set up a siege!',"126.

On $23^{\text {rd }}$ March 1968, the FSHPF was renamed Fédération Française de Sport pour Handicapés Physiques (FFSHP). While the articles of association scarcely differed ${ }^{127}$, the change was not minor: in fact, using the opening Fédération Française indicated its propensity to follow the federal sports model ${ }^{128}$. This change was no small matter since it occurred at the time when the links with the Youth and Sports administration were being consolidated. On $3^{\text {rd }}$ July 1968 , Volait met with Crespin. On $10^{\text {th }}$ July, he pressed for Gaudefroy to be authorised to accompany the team to the Paralympic Games in Tel Aviv ${ }^{129}$. On $14^{\text {th }}$ December, a cocktail party honouring the medals won at the Tel-Aviv Games brought together "important Parisian personalities", including a representative of the Secretary of State for Youth and Sports, Joseph Comiti ${ }^{130}$, who had held this post since $10^{\text {th }}$ July 1968. On $13^{\text {th }}$ January 1969 , following the spontaneous request by a member of the $A P F$ who had 
learned of the French participation in the $3{ }^{\text {rd }}$ Paralympic Games, Crespin indicated that "these athletes, whose merit has not escaped the Secretary of State (...) for Youth and Sports, have received rewards [medals of honour from the Ministry] attributed on $14^{\text {th }}$ December 1968 during a cocktail party". He hoped that the contacts made with the ORTF (French national Radio and TV broadcasting service) would lead to the production of "a program that would give back confidence to those with disabilities through the vector of sport"131.

\section{Decentralisation of the Institution}

In 1969, Volait failed to retain the presidency of the FFSHP. Although he had been elected for a year at the end of 1966, he kept the responsibility until $22^{\text {nd }}$ March 1969 - almost two and a half years. The 1969 election was held in a climate of defiance regarding the outgoing President, and also certainly one of internal tension. At the general meeting of March, "on the request of seven members of the Board, Mr. Avronsart announced his candidature for the presidency of the Federation"132. Volait announced his own candidature again. The count of the 55 votes was clear: with 3 abstentions, 48 votes were in favour of Avronsart and only 4 for Volait. While this election was a slap in the face for the outgoing President, Avronsart intended to continue the line taken by his predecessor with the $M S$. In this context he insisted on the need to "move very rapidly towards decentralisation"133. From March 1969, Morin, the new General Secretary, worked to set up Regional Committees. In April, the Board established three goals with "the full approval of the Department for Physical Education and Sport": setting up Regional Committees before the end of the year, organising "national propaganda" and enlarging the Board. The General Meeting interpreted decentralisation in a wider context: "Our sponsoring Ministry would like our main policy, just as for able-bodied sport where international credits have been reduced, to be based on sport 
for the majority of disabled. We have therefore decided, with the agreement of the Board, to devote a large part of our budget this season to promoting sport in the Regions."134

The plan for decentralisation found an echo in the philosophy of the administration of Youth and Sport, embodied by Marceau Crespin, who, from February 1961, was the General Delegate for Olympic Preparation, and in 1963, General Delegate for Sports and Olympic Preparation, before becoming Director for Sport on $15^{\text {th }}$ March 1965. Olivier Philip, Herzog's chief of staff from 1958 to 1964, remembered that although Crespin's work mainly concerned Olympic preparation, his basic idea was the overall development of sports, convinced of the relationship between the success of the sports elite and a mass participation to sports ${ }^{135}$.

On $5^{\text {th }}$ February 1970, Gaudefroy recalled a discussion between Crespin and Avronsart which took place on $30^{\text {th }}$ April 1969 and resulted in the decision to combine "isolated Associations into various Regional Committees". Crespin stressed that "the organisation of FFSHP was requested by the Board of the Federation and encouraged by the Department for Physical Education and Sport" (letter B 587 of $12^{\text {th }}$ June 1969) ${ }^{136}$. On $21^{\text {st }}$ October 1969 , Morin wrote to all the clubs. At the end of the year, the Federation newsletter mentioned that two Regional Committees had been set up, one in Provence, the other in Brittany, in addition to the three already established (in Ile-de-France, Flandre-Artois, Lyonnais-Forez-DauphinéSavoie).

At the start of 1970, the difficulties of decentralisation forced a reform of registrations for those with disabilities. The new system aimed to overcome the administrative constraints and also swell the numbers of "disabled athletes" - at least "on the files"137. The "second wind" that was hoped for did not occur. Avronsart however intended to continue the efforts for "decentralisation to provincial France". The requests and the voice of the State were not far off: "Mr. Comiti, Secretary of State for Youth, Sports and Leisure Activities, has shown his interest in our activities by granting an interview with the Federation and by agreeing to 
preside over the formal opening of the World Games at Saint-Etienne; but this will only prove effective if everyone really wants to take part; the decentralisation that we have initiated must be accompanied by a joint effort towards common goals."138

Setting up Regional Committees was still the priority: "It is obviously important that France is brilliantly represented in international meetings, but it is (...) much more important to develop sport at local, departmental and regional levels." Avronsart thanked those who were working with "local clubs, municipal authorities and rehabilitation centres, heads of companies, etc.". The Federation had thus accomplished its transformation. It had adopted sports ethos and at the same time decentralised its organisation, in the same way as the ablebodied sports federations, completing a process that had begun at the start of the $1960 \mathrm{~s}$.

\section{Epilogue: From an Association Formed for Rehabilitation Purposes to a Sports Federation with State Prerogatives}

The evolution of the sports movement for those with physical disabilities towards a federal model had a double implication - National and International. The beginning of the bias in favour of sports found its origins in organisations for the seriously injured, whose spirit influenced the first years of the $A S M F$ : "Bodily deficiency arouses both guilt and moral duty and leads to a medical and social reparatory philosophy. Society recognises its debt towards those who paid a heavy price, by replacing an amputated limb with an artificial one and attempting reintegration into the social place which was lost."139

Sports activities in the 1950s were discreet. There was no question of becoming champions, or fairground attractions, but simply of convincing the medical world and the public authorities of the rehabilitation opportunities offered to the seriously injured by taking part in sport. Until the end of the decade, the activities concerned remained within the scope of a pacifist plan to provide comradeship and mutual assistance that was developed for War 
Veterans, whether French, German or Austrian. In the United Kingdom, Italy or Japan, the practice of sports for the physically disabled was essentially developed within rehabilitation centres which could accommodate quadriplegic people on doctors' recommendations. In Switzerland, the model was dualistic, with two central associations, one of which was resolutely turned towards competitive sports, while the other was turned to a medical and noncompetitive approach, strongly influenced by its military origins ${ }^{140}$. In other countries, such as the United States for instance, a double approach, both medical and military, can be observed $^{141}$. In France ${ }^{142}$, rather like in Germany, in Austria, in Yugoslavia or in Slovenia ${ }^{143}$, it was on the impulse of wounded war veterans that sport for the physically disabled began to develop.

Despite their inclination for sports in this specific context, the leaders of the ASMF agreed with the discourse on the advantages to rehabilitation through sport, far removed from a competitive approach. International researcher often mainly highlight external factors, such as the social changes occurring during the 1960s that had an impact on abandoning the medical approach in favour of a competitive sports approach for treating those with disabilities ${ }^{144}$. In France, the transformation from a medical to a sports approach, adopting the quest for performance and the recognition of champions, was effected with a reorganisation of the support network of the Association in the early 1960s, when the weight of doctors and military personnel was put into perspective and somewhat minimised in view of the early ties established with the High Commission for Youth and Sport. While the established solidarity did not evaporate, the medical legitimacy of undertaking sport no longer appeared as the only possible way forward. A new prospect opened where the sports preferences of the pioneers could be expressed more directly. In the context of the early days of the $\mathrm{V}^{\text {th }}$ Republic, this prospect could count on the impetus of the Youth and Sports administration set up by Herzog, in powerful contrast with the weak political and financial levers available to the previous 
Director General of Physical Education and Sport, Gaston Roux.

In 1960, the first Paralympics Games took place. They acted as a trigger for the initiatives that were to lead to the founding of a Federation in 1963. At the same time, as was noted previously, the disastrous results of the able-bodied French athletes at the Rome Olympics contributed to accelerating the reforms which had been initiated by the newly born association for youth and sports and which aimed to propagate sports culture throughout France. The implementation of the federal sports model promoted by Herzog and orchestrated by Crespin was in progress. The leaders of the FSHPF saw an unexpected opportunity. The aim was to expand the number of participants in order to produce an elite, through a game of class structures and both regional and national selection, thus allowing France to shine in international competitions which are modelled on the Olympics. In 1967, one year after the founding by François Missoffe of the $M S$, the FSHPF strengthened its ties with the Youth and Sports administration, with which a permanent link would later be established through the intermediary of a delegate, Christian Gaudefroy. This close cooperation was related to the fact that the Federation was renamed FFSHP in 1968. In hastening the decentralisation which had been initiated to set up Regional Committees, this administration probably contributed to extending the expansion or growth crisis which lasted until the end of the 1970s.

The conditions necessary for founding a Delegatee Federation thus came together in 1970. However, a crisis accelerated the movement. Yves Nayme, who had failed to be elected when standing for president against Avronsart in 1971, shortly thereafter organised the " 1 st Winter Olympic Games for the physically disabled" at Courchevel, short-circuiting the Federation. Banned for life by the Federation, he set up his own organisation, the Fédération Française Omnisports des Handicapés Physiques (FFOPH) (French Federation for Omnisports for the Physically Disabled). He was shortly to be joined by the Association Sportive des Handicapés de Touraine ${ }^{145}$. Thus there was a real threat of competition. The 
founding of the FFOPH, to which Guttmann, president of the ISOD, said in a letter to Avronsart dated $22^{\text {nd }}$ February 1972 that he had "naturally" not given his assent, caused a division in the French disabled sport movement. Action had to be taken. Avronsart obtained a meeting with Crespin on $28^{\text {th }}$ February. A few days later, Crespin requested that "the possibility of according delegation powers" to the FFSHP be considered, so that it alone would have "the right to award titles of Champions of France to those with physical disabilities" 146 . On $16^{\text {th }}$ May, Guttmann addressed Comiti to advise him of the "terrible international repercussions" of the scission on sport for the physically disabled in France. On $10^{\text {th }}$ June, Comiti announced to Guttmann his decision to bestow the power of delegation to the FFSHP.

It was finally because of this crisis, which led to the birth of a dissident Federation, that the FFSHP obtained the status of Delegatory Federation on $20^{\text {th }}$ June 1972 . Colonel Crespin played a decisive role here. A native of Lozere of modest origins, he had great combative qualities and was close to Marshal de Lattre (under whose orders Berthe, Volait and Avronsart also served), and was to become, in 1975, president of Rhin et Danube ${ }^{147}$, the association through which the $A S M F$ came into being in 1954.

The process had come to its conclusion. The FFSHP had completed its transformation and adopted a sports approach. With the strength of its networks, its ties with the High Commission and subsequently those with the Ministry for Sport, it was firmly committed to the goals outlined by the latter - the availability of sport to the greatest number, encouraging the emergence of a sporting elite incorporating the dispositions for excellence of the FFSHP. The Federation thus ensured its dominance over the organisation of sports for those with disabilities. From there on, the place taken by the individual holding the title of disabled champion illustrated this evolution: in France, sport for those with disabilities would henceforth be based on the federal and competitive sports approach. 
The specificity of the history of French sport for the physically disabled is actually consecutive to two historical movements. On the one side, in the 1950s, a movement was born in which wounded veterans self-organised rehabilitation practices within a civilian framework $^{148}$, that is to say outside the boundaries of war veteran associations (to the opposite of what was done in Germany, for instance). On the other hand, in the 1960s, its affiliation to sporting federations models was facilitated, not only by the sporting leanings of the ASMF leaders, but also by the series of reforms initiated by the newly established administration for sports and youth. This is how the constitution of a multisport federation for all the physically disabled, as well as the reason for France's so singular voice within the international bodies of sports for the physically disabled, can be explained. At an early stage, it fought for sporting events to be both open to all forms of disability and to emulate the sporting model ${ }^{149}$, despite the regulating difficulties linked to organising competitions which can, at the same time, include all forms of disability while maintaining the principle of equality for all competitors, which is inherent to any sporting event.

\footnotetext{
${ }^{1}$ Henri-Jacques Stiker, Les Métamorphoses du Handicap de 1970 à nos Jours (Grenoble: PUG, 2009), 64. In France, even though it refers more to mental than to physical disability, a relevant work is Roy Compte, Gilles Bui-Xûan and Jacques Mikulovic, eds., Sport Adapté, Handicap et Santé (Montpellier: Afraps-FFSA, 2012).

${ }^{2}$ Sébastien Ruffié and Sylvain Ferez, eds., Corps, Sport, Handicaps. L'Institutionnalisation du Mouvement Handisport 1954-2008 (Paris: Téraèdre, 2013).

${ }^{3}$ For example, see André Auberger, ed., La Même Flamme. 50 ans de Défis et d'Exploits Handisports (Paris: Le Cherche Midi, 2005). André Hennaert, Du Djebel aux Jeux Paralympiques (Paris: L’Harmattan, 2010).

${ }^{4}$ Steve Bailey, Athlete First. A History of the Paralympic Movement (Chichester: Wiley, 2008). Ian Brittain, "South Africa, apartheid and the Paralympic Games," Sport in Society 14(2011) 9: 1165-81. Susan Goodman, The Spirit of Stoke Mandeville. The Story of Sir Ludwig Guttmann (London: Collins, 1986).
} 
${ }_{5}^{5}$ Sylvain Ferez, Julie Thomas and Sébastien Ruffié, "De l'auto-organisation des mutilés de guerre à la structuration d'une Fédération sportive pour handicapés physiques : la spécificité de la France (1954-1972)," European Studies in Sport History 8(2015): 121-48.

${ }^{6}$ Antoine Prost, "Les anciens combattants," in Histoire des Mouvements Sociaux en France, eds. Michel Pigenet, and Danielle Tartakowsky (Paris: La Découverte, 2014), 316-23.

${ }^{7}$ The status of Delegatee Federation, was granted by the Government Decree of $28^{\text {th }}$ August 1945, bestows upon the organisation certain obligations. In marshalling all the local associations pertaining to the same speciality, it is under a public service delegation contract. Endowed with the responsibility for organising athletic events in their specific discipline, and protected against any competition from other associations, it is competent and has the exclusive rights for organising international, national, regional and local sporting events and for giving awards and titles, thus performing a public administrative service.

${ }^{8}$ See for example. Michel Crozier and Erhard Friedberg, L'Acteur et le Système: les Contraintes de l'Action Collective (Paris: Seuil, 1977). Henry Mintzberg, The Structure of Organizations. A Synthesis of the Research (London: Englewood Cliffs, Prentice-Hall, 1979).

${ }^{9}$ John R. Gold and Margaret Gold, “Access for All: the Rise of the Paralympic Games," The Journal of the Royal Society for the Promotion of Health 127(2007)3: 133-41. David Legg and Robert D. Steadward, "The Paralympic Games and 60 Years of Change (1948-2008): Unification and Restructuring from a Disability and Medical Model to Sport-based Competition," Sport in Society 14(2011)9: 1099-15. Robert D. Steadward and Susan L. Foster, "History of Disability Sport: From Rehabilitation to Athletic Excellence," in Adapted Physical Activity, eds. Robert D. Steadward, Jane E. Watkinson, and Gary D. Wheeler (Edmonton: University of Alberta Press, 2003): 471-96.

${ }^{10}$ Michaël Attali and Jean Saint-Martin, "Le rôle de l'école dans la genèse d'une culture sportive de Masse," Vingtième Siècle 95(2007): 181-92.

${ }^{11}$ Jean-Luc Martin, "Les malentendus de l'éducation physique: réussites et déceptions d'une stratégie politique," in Maurice Herzog. Un Septennat pour une Politique Jeunesse et Sports, eds. Denise Barriolade, Laurent Besse and Arnaud Loustalot (Paris: La documentation Française, 2013): 54.

${ }^{12}$ Mariane Amar, Nés pour Courir: la Quatrième République face au Sport (Grenoble: PUG, 1987). Mariane Lassus, "Gaston Roux, the anti-Herzog ?," in Maurice Herzog, eds. Barriolade, Besse and Loustalot, 23-33.

${ }^{13}$ Jean-Luc Martin, La Politique de l'Éducation Physique sous la Ve République. 1. L'Élan Gaullien 1958-1969 (Paris: PUF, 2004) 
${ }^{14}$ Laurent Besse, “Jeunesse et sports enfin seuls ! Rapports avec l'éducation nationale,” in Maurice Herzog, eds. Barriolade, Besse and Loustalot, 35-48.

${ }^{15}$ Amar, Nés pour Courir. Martin, La Politique de l'Éducation Physique.

${ }^{16}$ Attali and Saint-Martin, "Le rôle de l'école...".

${ }^{17}$ National archives, F44bis 6074. In addition to this file the box contains two others on the "Nayme case: FFOHP” (1972-1974) and on the "Plan to set up a Brevet d'État [State Diploma of Sports Coach]" (1972-1974).

${ }^{18}$ National archives, F44bis 6073.

${ }^{19}$ The complete collection of these bulletins is available in digital format at the National Library of France.

${ }^{20}$ As well as other primary sources, such as the administrative documents of the Association Sportive des Handicapés Physiques de la Loire, a base of video documentaries stored at the Saint-Étienne film library, the personal archives of a number of protagonists, and local press cuttings.

${ }^{21}$ French Omnisport Federation for the Physically Disabled.

${ }^{22}$ Florence Descamps, ed., Les Sources Orales et l'Histoire. Récits de Vie, Entretiens, Témoignages Oraux (Paris: Bréal, 2006).

${ }^{23}$ Robert Castel, L'Insécurité Sociale. Qu'Est-ce qu'Être Protégé ? (Paris: Broché, 2003).

${ }^{24}$ Cf. Henri-Jacques Stiker, Corps Infirmes et Société (Paris: Dunod, 1997). Stiker, Les Métamorphoses du Handicap.

25 The Association for the Paralysed of France.

${ }^{26}$ Nathan Breen, Moteur! 70 ans de Combats 1933-2000 (Paris: APF, 2003).

${ }^{27}$ Catholic Association for the Sick at Berck (a sanatorium near Calais treating cases of tuberculosis).

${ }^{28}$ The League for Adapting the Physically Diminished for Employment.

${ }^{29}$ Stéphane Audouin-Rouzeau and Chritophe Prochasson, eds., Sortir de la Grande Guerre, le Monde et l'Après1918 (Paris: Tallandier, 2008).

${ }^{30}$ Marianne Lassus, "Débat général”, in Maurice Herzog, eds. Barriolade, Besse and Loustalot, 75.

${ }^{31} R M F$, October, 1955, 1.

${ }^{32} R M F$, November, 1957,8 .

${ }^{33} R M F$, June, 1958, 10: 8.

${ }^{34}$ Jacques Martin, “Le mot du secrétaire général,” $R M F$, October, 1956, 4: 3.

${ }^{35}$ P. B., "L'ASMF dans le monde: Rencontre à Constance", $R M F$, November, 1957, 8.

${ }^{36}$ Jacques Martin, "Réunion amicable internationale,” RMF, Mai, 1959, 12: 11-13. 
${ }^{37}$ Wolf Donner, Die Sozial- und Staatspolitische Tätigkeit der Kriegsopferverbände (Berlin: Beitrag zur Verbandsdiskussion, 1960).

${ }^{38}$ M. ZeInINGer, "Report on experiences in the Sport Sanatorium Isny," Archiv für Orthopädische und UnfallChirurgie, 48(1956)2: 237-242.

${ }^{39}$ Jean R. N., "Sport - Sanatorium d'Ysny,” RMF, June, 1958, 10: 14.

${ }^{40} I d$.

${ }^{41} I d$.

${ }^{42}$ Dr Bräuninger published a book in 1956 Die Heilgymnastische Kur im Sportsanatorium Isny als Heilmassnahme der Rehabilitation und Prävention [literally: Healing Gymnastics Therapy at the SportSanatorium of Isny as a Curative measure for Rehabilitation and Prevention].

43 “Anticipation," RMF, May, 1959, 12: 15.

${ }^{44}$ Le Secrétaire Général, “Amicale sportive des mutilés de France,” $R M F$, February, 1956, 1: 6.

${ }^{45} I d$.

46 “Communiqué," $R M F$, January, 1957, 5: 3.

${ }^{47}$ P. G., "Editorial," RMF, April, 1957, 6: 3.

${ }^{48} I d$.

${ }^{49}$ She married a parachute officer who fought at Dien Bien Phu.

${ }^{50}$ Interview with A. Berthe, 14 September 2009.

${ }^{51}$ Interview with P. Volait, 22 February. For Avronsart, consult the article published online on 29 May 2009 by Denise Hoba: http://perso.pierrefitte93.fr/ dhoba/spip.php?article14.

${ }^{52}$ As some historians examine the entourage of heads of state. Cf. Gilles Le Béguec, "Avant-propos. Les entourages des chefs de l'État, de Mac-Mahon à Valéry Giscard d’Estaing," Histoire@Politique. Politique, culture, société 8(2009), http://www.histoire-politique.fr/index.php?numero=08.

${ }^{53}$ Interview with A. Berthe, 14 September 2009.

${ }^{54}$ Ivan Cadeau, "1954-1956, le départ du corps expéditionnaire français d'Extrême-Orient," Revue historique des armées 258(2010): 67-81.

${ }^{55}$ This was the case with the first two presidents, P. Berthe (interview with his widow on 14 September 2009) and P. Volait (interview on 22 February 2011), while the third president, Marcel Avronsart, signed up at 21 (in 1942) from Brazil.

${ }^{56}$ Sylvie Guillaume, Confédération Générale Petites Moyennes Entreprises. Son Histoire, son Combat, un Autre 
Syndicalisme Patronal 1944-1978 (Bordeaux: Presse Universitaire de Bordeaux, 1987).

${ }^{57}$ Pierre Poujade was the leader of the most extremist and concervative wing of retail traders and artisans.

${ }^{58}$ Frédéric Tristram, "Combat d'arrière-garde ou mouvement social précurseur ? Le poujadisme à la croisée des analyses," in Histoire des Mouvements Sociaux en France, eds. Michel Pigenet and Danielle Tartakowsky (Paris: La Découverte, 2014), 446-55.

${ }^{59}$ René Bargeton, Dictionnaire biographique des préfets 1870-1982 (Paris: Archives nationales, 1994).

${ }^{60}$ Jean-Marie Guillon, "La Résistance dans le Var: Essai d'Histoire Politique" (PhD diss., Université d'AixMarseille 1, 1989): 31.

${ }^{61}$ Robert Buron, Les Dernières Années de la IVe République. Carnets politiques (Paris: Plon, 1968) ; Marcel Launay, Robert Buron, témoignages de Pierre Pflimlin et Jean Offredo (Paris: Cana, 1993).

${ }^{62}$ Stiker, Corps Infirmes et Société, 187.

${ }^{63} I d ., 166$.

${ }^{64}$ Christel Coton, "Briller sous l'épaulette. Capital culturel et capital combattant dans le corps des officiers de l'armée de terre," Actes de la Recherche en Sciences Sociales 191-192(2014): 14-27.

${ }^{65}$ Interview with P. Cochard, 15 September 2009.

${ }^{66} R M F$, October, $1955,1$.

${ }^{67}$ Le Toubib, "Vouloir !," $R M F$, May, 1956, 3: 5-7.

${ }^{68}$ Eric Levet-Labry, 'L’Institut National des Sports de 1945 à 1976: du Militantisme Sportif à l'Organisation Rationnelle d'une Politique Sportive," in L'Empreinte de Joinville: 150 ans de Sport (1852-2002), eds. Pierre Simonet and Laurent Veray (Paris: Les Cahiers de l'INSEP, 2003): 107-19.

${ }^{69}$ According to the expression of Olivier Le Noé, "Socio-histoire des Politiques Sportives (1940-1975). Genèse d'un Groupe de Spécialistes de l'Administration d'État des Activités Sportives et Structuration du Service Public du Sport" (PhD diss., Université Paris I, 2000): 439.

${ }^{70}$ Amar, Nés pour Courir.

${ }^{71}$ Thibault Tellier, "Jalons pour une biographie. Itinéraire politique d'un gaulliste engagé", in Maurice Herzog, eds. Barriolade, Besse and Loustalot, 81.

${ }^{72}$ Laurent Besse, "Maurice Herzog, un septennat pour une politique jeunesse et sports," in Maurice Herzog, eds. Barriolade, Besse and Loustalot, 11.

${ }^{73}$ Barriolade, Besse and Loustalot, eds., Maurice Herzog, 67. Regarding the sanitary aspects, the vision of Roux is expressed in a handwritten citation on the plans for stadiums in the second half of the 1930s: "Opening a 
stadium closes a hospital." (National Archives, Paris site, F17 14460, “Conseils pour l'aménagement d'un stade communal", brochure published by the management of sports, leisure and physical education, cited by Lassus, “Gaston Roux, the anti-Herzog?”, 26.

${ }^{74}$ Interview with A. Berthe, 14 September 2009.

${ }^{75}$ Interview with H. Tanguy, 10 June 2009.

${ }^{76}$ Interview with P. Volait, 22 February 2011.

${ }^{77}$ Jacques Martin, “L’ASMF et les jeux de Rome,” ASMF Mag, July-August, 1960, 18: 8.

${ }^{78}$ Patrick Clastres, "La mobilisation sportive des Français dans les années 1960. Laver l'affront des Jeux Paralympics de Rome," in Maurice Herzog, eds. Barriolade, Besse and Loustalot, 166.

${ }^{79}$ Alain Peyrefitte, C'était de Gaulle (Paris: Gallimard: 2002).

${ }^{80}$ Le Noé, “Socio-histoire des politiques sportives (1940-1975)".

${ }^{81}$ Clastres, "La mobilisation sportive des Français dans les années 1960," 167.

${ }^{82}$ Philippe Berthe, "Le mot du Président," ASMF Mag, July-August, 1960, 19: 2.

${ }^{83}$ Maurice Herzog, “Courrier,” ASMF Mag, July-August, 1960, 19: 5.

${ }^{84}$ Armand Massard, “Courrier,” ASMF Mag, July-August, 1960, 19: 6.

${ }^{85}$ Jacques Martin, “Echos sur les Jeux de Rome,” ASMF Mag, December-January, 1960-61, 20: 5.

${ }^{86}$ Sébastien Ruffié, Sylvain Ferez and Elise Lantz, "From the Institutionalization of 'all disabilities' to Comprehensive Sports Integration: The Enrolment of France in the Paralympic Movement 1954-2012," The International Journal of the History of Sport, 31(2014)17: 2245-65.

${ }^{87}$ ASMF Mag, $2^{\text {nd }}$ trimester, 1963,31 , cover page 2.

${ }^{88}$ Denis J. Frost, "Tokyo's other Games: The Origins and Impact of the 1964 Paralympics," The International Journal of the History of Sport 29(2012)4: 619-37.

${ }^{89}$ Julie Anderson, “'Turned into Taxpayers': Paraplegia, Rehabilitation and Sport at Stoke Mandeville, 19441956," Journal of Contemporary History 38(2003)3: 461-75. Gold and Gold, “Access for All: the Rise of the Paralympic Games".

${ }^{90}$ Danielle Peers, "Patients, Athletes, Freaks: Paralympism and the Reproduction of Disability," Journal of Sport and Social Issues 36(2012)3: 295-16.

${ }^{91}$ Ruffié, Ferez and Lantz, "From the Institutionalization...".

${ }^{92}$ Ian Brittain, The Paralympic Games Explained (London: Routledge, 2010).

${ }^{93}$ Michel Boubée, "Le groupement international d'étude des sports pour handicaps," ASMF Mag, April-March, 
1961, 22: 13 .

94 "Notes et commentaires sur les résultats de la reunion du comité sportif du groupement international," ASMF Mag, September-October, 1961, 24: 5.

${ }^{95}$ As shown by an article in the Swiss Federal press in 1968 written by Marcel Meier, "Der Präsident der TK spricht: Who stehen wir?,” [“The President of TK says: who are we?”) Sport-Handicap, 1968, 4: 3-7.

96 "Conseil international des sport pour handicaps," Second Souffle, June, 1964, 2: 8.

${ }^{97}$ Interview with H. Tanguy, 10 June 2009. Herzog lost his fingers climbing the Annapurna in 1950.

${ }^{98}$ Philippe Berthe, "Faisons le point," ASMF Mag, $4^{\text {th }}$ trimester, 1963, 33: 2.

${ }^{99}$ Interview with H. Tanguy, 10 June 2009.

${ }^{100}$ Gildas Loirand, "L'État et le sport en France. De l'intervention autoritaire à la démission," Savoir/Agir 15(2011)1: 15 .

${ }^{101}$ Berthe, "Faisons le point".

102 “La federation sportive des handicapés physiques de France," Second Souffle, March, 1964, 1: 3.

${ }^{103}$ Interview with A. Hennaert, 17 February 2009.

${ }^{104}$ Pierre Volait, "Editorial," Second Souffle, $3^{\text {rd }}$ trimester, 1968, 19: 2.

${ }^{105}$ Pierre Clerc, "Nos résultats sportifs de l'année. Haltérophilie," Second Souffle, $3^{\text {rd }}$ trimester, 1967, 15: 5.

${ }^{106}$ Adrien Gerber, "Natation” Second Souffle, $3^{\text {rd }}$ trimester, 1967, 15: 6.

${ }^{107}$ Michel Belin, “Tennis de table,” Second Souffle, $3^{\text {rd }}$ trimester, 1967, 15: 7.

${ }^{108}$ Adrien Gerber, "Natation. Championnat de France (tous handicap) - Novembre 1968 - Paris," Second Souffle, $3^{\text {rd }}$ trimester, 1968, 20: 20.

${ }^{109}$ René David, "Remarque en vrac sur le tir à l'arc," Second Souffle, $4^{\text {th }}$ trimester, 1968, 20: 15.

${ }^{110}$ Pierre Volait, "Présent et avenir," Second Souffle, $4^{\text {th }}$ trimester, 1968, 20: 2-3.

${ }^{111}$ Pierre Clerc, "L’haltérophilie couchée," Second Souffle, $3^{\text {rd }}$ trimester, 1969, 23: 7.

${ }^{112}$ Guy Bocle, "Tennis de table, Championnat de France (tous handicaps) - 18 mai 1969 - Saint Maur," Second Souffle, $2^{\text {nd }}$ trimester, 1969, 22: 7.

113 Jean Perry, "Championnat de France (tous handicaps) - 22 juin 1969 - Montmorillon (Vienne)," Second Souffle, $2^{\text {nd }}$ trimester, 1969, 22: 7.

${ }^{114}$ Philippe Berthe, “Athlétisme,” Second Souffle, $3^{\text {rd }}$ trimester, 1969, 23: 15.

${ }^{115}$ Implicitly, distinguishing the women and the youths shows just how much conforming to the "able-bodied" federal model also entails conforming to the hegemonic masculinity on which this model is based, cf. Raewyn, Connell, Masculinités. Enjeux sociaux de l'hégémonie (Paris: Ed. Amsterdam, 2014). 
${ }^{116}$ Interviews with A. Berthe (14 September 2009) and P. Volait (22 February 2011).

117 “Assemblée Générale du 26 novembre 1966,” Second Souffle, $4^{\text {th }}$ trimester, 1966, 12: 3.

${ }^{118} I d$.

${ }^{119}$ Interview with A. Siclis, 7 April 2009.

${ }^{120}$ Pierre Volait, "Editorial," Second Souffle, $4^{\text {th }}$ trimester, 1967, 16: 2.

${ }^{121}$ Huguette Tanguy, “Assemblée Générales du 23 mars 1968,” Second Souffle, $1^{\text {st }}$ trimester, 1968, 17: 5.

${ }^{122} I d ., 9$.

${ }^{123}$ Pierre Volait, "Responsabilité," Second Souffle, 2nd trimester, 1968, 18: 2.

${ }^{124}$ National Archives, F44bis 6074.

${ }^{125}$ Jean-Paul Callède, “Les politiques du sport en France,” L'Année sociologique 52(2002)2 : 437-57. Moreover, Crespin strengthens his management of the sporting movement by assigning technicians from the administration for youth and sports to the sporting federations. On 10th June, 1966, he signed a memorandum which, as a follow up for the 5th April 1957 one (creating a body of national sporting Counselors assigned to the federations), details the precise functions of the National Technical Director or DTN (National archives, F44bis 10521). Cf. Olivier Le Noé, "Marceau Crespin a-t-il existé ? Éclairages sur une éclipse historiographique de l'analyse des politiques gaullistes du sport," Sciences sociales et sports 7(2014): 11-41. Jérémy Pierre, "Des brevets d'État d'éducateur sportif aux diplômes professionnels de 1963 à nos jours. Réflexion sur les enjeux et débats relatifs aux réformes du tronc commun," in Les éducateurs sportifs en France depuis 1945. Questions sur la professionnalisation, eds. Denis Bernardeau-Moreau and Cécile Collinet (Rennes : PUR, 2009), 109-50.

${ }^{126}$ Interview with H. Tanguy, 10 June 2009.

${ }^{127}$ Second Souffle, $1^{\text {st }}$ trimester, 1968, 17.

${ }^{128}$ Today the Sports Code stipulates: "With the exception of sports federations approved with effect from 16 July 1992, only delegatee sports federations may use the title "French Federation of" or "National Federation of" and thereby award or allow the award of the title "French Team" and "French Champion", followed by the name of one or several sports disciplines and have it mentioned in their Articles of Association, contracts, documents or publicity" (Sports Code, section 3, article L131-17).

${ }^{129}$ National archives, F44bis 6074.

${ }^{130}$ Huguette Tanguy, “Cocktail du 14 décembre 1968," Second Souffle, $4^{\text {th }}$ Trimester, 1968, 20: 26.

${ }^{131}$ National archives, F44bis 6074.

132 "Elections," Second Souffle, $1^{\text {st }}$ Trimester, 1969, 21: 7. 
${ }^{133}$ Marcel Avronsart, “Editorial,” Second Souffle, $1^{\text {st }}$ Trimester, 1969, 21: 2.

${ }^{134}$ Michel Belin, "Compte rendu des activités de la commission sportive en 1969," Second Souffle, $2^{\text {nd }}$ trimester, 1969, 25: 8 .

${ }^{135}$ Olivier Philip, in Maurice Herzog, eds. Barriolade, Besse and Loustalot, 105.

${ }^{136}$ National archives, F44bis 6074.

${ }^{137}$ Guy Genin, "La vie fédérale," Second Souffle, $1^{\text {st }}$ trimester, 1970, $24: 3$.

${ }^{138}$ Marcel Avronsart, “Collaboration et amitié," Second Souffle, $2^{\text {nd }}$ trimester, 1970, $25: 2$.

${ }^{139}$ Jean-Jacques Courtine, Déchiffrer le Corps (Paris: Million, 2011), 130-131.

${ }^{140}$ Julie Comaton's thesis, concerning a comparative study of the institutionalisation of associations which are dedicated to paraplegics' physical activities in Switzerland, should soon (2016) clarify this unusual configuration.

${ }^{141}$ Horst Strohkendl, The 50th Anniversary of Wheelchair Basketball: A History (New York: Waxmann, 1996).

${ }^{142}$ Ruffié and Ferez, Corps, Sport, Handicaps.

${ }^{143}$ Mojca D. Topic, "The Rise of Paralympic Sport in Slovenia," in The Paralympic games. Empowerment or side Show?, eds. Keith. Gilbert and Otto J. Schantz (Maidenhead: Meyer \& Meyer, 2008), 212-20.

${ }^{144}$ Ian Brittain, "The Paralympic Games as a Force for Peaceful Coexistence," Sport in Society 15(2012)6: 85568. Robert. D. Steadward and Siena L. Foster, "History of Disability Sport: From Rehabilitation to Athletic Excellence", in Adapted Physical Activity, eds. Robert D. Steadward et al. (Edmonton: The université of Alberta Press, 2003), 471-96. Gold and Gold, “Access for All: the Rise of the Paralympic Games”. Legg and Steadward, "The Paralympic Games and 60 Years of Change (1948-2008)".

${ }^{145}$ Anne Marcellini, Marie Courrouy-Michel and Mai-Ahn Ngo, "La scission (1972-1977): Les années FFOHP," in Corps, Sport, Handicaps, eds. Sébastien Ruffié and Sylvain Ferez (Paris:Téraèdre, 2013), 91-105.

${ }^{146}$ National archives, F44bis 6074. The information on the interview between Avronsart and Crespin of the $28^{\text {th }}$ February comes from a note passed by bureau S.2 to bureau S.3 of the Department for Physical Education and Sport on $3^{\text {rd }}$ March 1971.

${ }^{147}$ Le Noé, "Marceau Crespin a-t-il existé ?".

${ }^{148}$ To the opposite of what can be observed in the United Kingdom or in Italy, for instance, where it is the doctors who organise these practices.

${ }^{149}$ Ruffié, Ferez and Lantz, "From the Institutionalization...”. 